\title{
Soil degradation due to heavy metal accumulation under long term fertilization of paddy (Oryza sativa $\mathbf{L}$.)
}

\author{
E. Parameswari ${ }^{1 *}$, V. Davamani ${ }^{2}$, S. Arulmani ${ }^{1}$ and A. Rathinasami ${ }^{2}$ \\ ${ }^{1}$ Tamilnadu Rice Research Institute, Aduthurai, INDIA \\ ${ }^{2}$ Horticultural College and Research Institute, Periyakulam, Tamil Nadu Agricultural University (Tamil Nadu), \\ INDIA \\ *Corresponding author. E-mail: parameswariphd@ gmail.com \\ Received: January 13, 2014; Revised received: April 22, 2014; Accepted: May 1, 2014
}

\begin{abstract}
Long term fertility experiment (LTFE) under double rice cropping system was investigated in Tamil Nadu Rice Research Institute, Aduthurai, India with two varieties (ADT 43 and ADT 45) in two seasons (Kharif and Rabi) under six fertilizer treatments to study the heavy metal accumulation in soil and its impact on paddy. There was a significant variation in physico-chemical properties of soil due to different fertilizer treatments. The surface soil $(0-15 \mathrm{~cm}$ soil depth) in all the treatments showed relatively higher heavy metal accumulation than subsurface. In the long run, there was a build up in the total heavy metal content in soil and it was found to be relatively high in phosphatic fertilizer applied treatments than others. Total $\mathrm{Cd}$ and $\mathrm{Pb}$ was found high, but the availability was below detectable limit indicated that $\mathrm{Cd}$ and $\mathrm{Pb}$ were found in unavailable forms, while $\mathrm{Cu}$ and $\mathrm{Zn}$ were slightly in mobile forms which had been translocated into grain and straw of paddy. The DTPA (Diphenyl Triamine Penta Aceticacid) extractable $\mathrm{Cd}$ and $\mathrm{Pb}$ in the soil was low, but there was heavy increase in $\mathrm{Cu}$ and $\mathrm{Zn}$ comparing with initial period. The rate of increase in $\mathrm{Cd}$ and $\mathrm{Pb}$ content was lower in $\mathrm{N}$ alone and control plots. This might be due to the long term application of phosphotic and zinc sulphate fertilizers. $\mathrm{Cd}$ and $\mathrm{Pb}$ were evenly distributed at low concentrations in grain and straw under various treatments. In case of $\mathrm{Cu}$ and $\mathrm{Zn}$, it was relatively higher in grains and paddy straw among various fertilizer treatments. There was no significant difference among the varietal (seasons) treatments for the accumulation of heavy metals in grain and straw.
\end{abstract}

Keywords: Fertilizer, Grain, Heavy metal, Paddy, Straw

\section{INTRODUCTION}

The loading of agricultural ecosystem with heavy metals can be due to excessive fertilizer and pesticide use, irrigation, atmospheric deposition, and pollution by waste materials. Increased environmental concern is frequently expressed now a days about the concentration of heavy metals especially $\mathrm{Cd}$ and $\mathrm{Pb}$ and their possible effect on human beings after entering into food chain through the food crops raised in such heavy metal contaminated soils. Phosphatic fertilizers like single super phosphate derived from the phosphatic rocks are the chief sources of heavy metals like $\mathrm{Cd}$ and $\mathrm{Pb} . \mathrm{Cd}$ is a biologically non essential element which is a most dangerous environmental pollutant because of its diverse toxic effects. When it enters into the food chain of higher animals it is stored in the liver and kidney and causes bone deformities and kidney damage in human beings. $\mathrm{Pb}$ is another heavy metal which also find its way to the soil through phosphatic and zinc fertilizers in addition to the major pollution sources like petroleum emission from motor vehicles (Mousavi, 2010). Phosphatic fertilizers are indispensable in modern agriculture, although a reduction in the heavy metal concentration of them made from high heavy metal containing phosphate rocks is technically possible but it may be difficult to justify economically. ISSN : 0974-9411 (Print), 2231-5209 (Online) All Rights Reserved @ Applied and Natural Science Foundation www.ansfoundation.org
Hence, it becomes a necessary evil to apply heavy metal contained fertilizers, which are the sources of pollution. Though their concentration is soils, as of now, may be negligible, in the long run incorporation of fertilizers such as single super phosphate may pose serious problem which necessitates close monitoring. The micro nutrients such as $\mathrm{Cu}$ and $\mathrm{Zn}$ are essential for paddy crop growth, though their higher concentration will not affect the crop growth as like $\mathrm{Cd}$ and $\mathrm{Pb}$ because of its properties classified under heavy metals. Higher concentration of heavy metals in the soil would increase the potential uptake of metals by plants. The best tool to monitor the heavy metal accumulation in agricultural soils is the long term fertilizer experiments, where in each treatment receives specified quantity of fertilizers every crop season (Palaniappan et al., 2002). With a view to assess the effect of continues fertilizer application on total and DTPA extractable cadmium, lead, copper and zinc levels in soil and paddy crop under long term fertilizer experiment (LTFE) is in progress at Tamilnadu Rice Research Institute, Tamilnadu Agricultural University, Aduthurai, India.

\section{MATERIALS AND METHODS}

This LTFE was initiated in the year 1994 in a black 
soil (Udorthentic chromusterts). The experimental soil is clay loam in texture with a $\mathrm{pH}$ of 6.9 and cation exchange capacity of $40.5\left(\mathrm{c}\right.$ mol $\left.\left(\mathrm{p}^{+}\right) \mathrm{kg}^{-1}\right)$. The organic carbon content is around $0.57 \%$. This experiment was initiated with two varieties in six fertilizer treatments under split plot design. Rice varieties ADT 43 and ADT 45 are main treatments and different levels of $\mathrm{N}, \mathrm{P}$ and $\mathrm{K}$ as sub treatments. Totally twelve treatments were compared in both Kharif and Rabi seasons. The details of the treatments are listed below.

Main plot treatments: (Promising rice varieties)

\begin{tabular}{cccccccc}
\hline \multirow{2}{*}{ Treatments } & \multicolumn{3}{c}{ Kharif (kg/ha) } & \multicolumn{3}{c}{ Rabi (kg/ha) } \\
\cline { 2 - 8 } & $\mathbf{N}$ & $\mathbf{P}_{\mathbf{2}} \mathbf{O}_{\mathbf{5}}$ & $\mathbf{K}_{\mathbf{2}} \mathbf{O}$ & $\mathbf{N}$ & $\mathbf{P}_{\mathbf{2}} \mathbf{O}_{\mathbf{5}}$ & $\mathbf{K}_{\mathbf{2}} \mathbf{O}$ \\
\hline $\mathrm{T}_{1}$ & Control & 0 & 0 & 0 & 0 & 0 & 0 \\
$\mathrm{~T}_{2}$ & $+\mathrm{PK}$ & 0 & 80 & 120 & 0 & 57.3 & 90 \\
$\mathrm{~T}_{3}$ & $+\mathrm{N}$ & 150 & 0 & 0 & 132 & 0 & 0 \\
$\mathrm{~T}_{4}$ & $+\mathrm{NP}$ & 150 & 80 & 0 & 132 & 57.3 & 0 \\
$\mathrm{~T}_{5}$ & $+\mathrm{NK}$ & 150 & 0 & 120 & 132 & 0 & 90 \\
$\mathrm{~T}_{6}$ & $+\mathrm{NPK}$ & 150 & 80 & 120 & 132 & 57.3 & 90 \\
\hline
\end{tabular}

Kharif: Variety 1: ADT 43, Variety 2: ADT 45

Rabi : Variety 1: ADT 38, Variety 2: ADT 39

Sub plot treatments (Inorganic fertilizers): $\{\mathrm{N}$ applied as 3 splits at 15, 30 and 45 DAT (Days After Transplanting) in Kharif and 15, 35, 50 and 70 DAT in Rabi, $\mathrm{P}$ applied as full basal, $\mathrm{K}$ applied in two splits (50\% basal, 50\% at panicle initiation) and $\mathrm{ZnSO}_{4} @$ $25 \mathrm{~kg} \mathrm{ha}^{-1}$ common to all $\}$.

A fixed crop rotation of rice-rice- rice fallow pulses in a year is being followed year after year, rice fallow pulses were grown without fertilizers. The mean $\mathrm{Cd}$ and $\mathrm{Pb}$ content of single superphosphate, the $\mathrm{P}$ source, are 70 and $106 \mathrm{mg} \mathrm{kg}^{-1}$, respectively. The irrigation water had $<1.0 \mathrm{mg} \mathrm{L}^{-1}$ of $\mathrm{Cd}$. Commencing from the year 1994 post harvest surface soil samples after each crop are collected and preserved for future use. Soil samples from 1994 and 2010 crop seasons were evaluated for DTPA extractable and total $\mathrm{Cd}$ and $\mathrm{Pb}$ contents following the methods suggested by Lindsay and Norvell (1978) and USEPA (1979), respectively.

\section{RESULTS AND DISCUSSION}

The soil of the experimental site was fine montmorillonitic, isohyperthermic, $U$. chromusterts with heavy clay texture which belonged to Kalathur soil series.

Physico-chemical properties of soil: Soil physicochemical parameters were estimated during initiation of the experiment as well also at the $16^{\text {th }}$ year and the results are presented in tables 1 and 2 . Soil fertility status at the end of $16^{\text {th }}$ year (2010) showed marked variations when compared to initial status (1994). The soil $\mathrm{pH}$ and Electrical Conductivity (EC) showed only marginal variations over the years as well as among the treatments. However, there is a slight significant variation of increasing the $\mathrm{pH}$ and $\mathrm{EC}$ due to the effect of treatments in the $16^{\text {th }}$ year $\left(32^{\text {th }}\right.$ crop). Though, there were some fluctuation in $\mathrm{pH}$ values in the treatments varied between 7.16 (absolute control) to 7.22 (NPK), these values are within the neutral range of a rice
Table 1. Initial soil properties of long-term fertility experiment during 1994 (Before 16 years).

\begin{tabular}{lc}
\hline Properties & Value \\
\hline $\mathrm{pH}(1: 2)$ & $6.9+0.02$ \\
$\mathrm{EC}\left(\mathrm{dS} \mathrm{m}{ }^{-1}\right)$ & $0.49+0.01$ \\
Clay $(\%)$ & $46.53+0.01$ \\
Water holding capacity $(\%)$ & $38.9+2.6$ \\
Bulk density $\left(\mathrm{g} \mathrm{cm}^{-3}\right)$ & 1.50 .01 \\
Organic C $(\%)$ & $0.57+0.02$ \\
Free CaCO3 $(\%)$ & $0.55+0.02$ \\
$\mathrm{CEC}\left(\mathrm{c} \mathrm{mol}\left(\mathrm{p}^{+}\right) \mathrm{kg}^{-1}\right)$ & $40.5+1.2$ \\
Available $\mathrm{N}(\mathrm{kg} / \mathrm{ha})$ & $231+3.1$ \\
Available $\mathrm{P}(\mathrm{kg} / \mathrm{ha})$ & $30+4.2$ \\
Available $\mathrm{K}(\mathrm{kg} / \mathrm{ha})$ & $228+2.6$ \\
Available $\mathrm{Zn}(\mathrm{mg} / \mathrm{kg})$ & $1.2+0.02$ \\
Available $\mathrm{Cu}(\mathrm{mg} / \mathrm{kg})$ & $2.2+0.02$ \\
Available $\mathrm{Cd}(\mathrm{mg} / \mathrm{kg})$ & $\mathrm{BDL}$ \\
Available Pb $(\mathrm{mg} / \mathrm{kg})$ & $\mathrm{BDL}$ \\
\hline
\end{tabular}

BDL: Below Detectable Limit

system (Ponnamperuma, 1972). The soil's ability to immobilize heavy metals increases with rising $\mathrm{pH}$ and peaks under mildly alkaline conditions. In acid soils (pH 4.2 to 6.6) the mobility of $\mathrm{Cd}$ and $\mathrm{Zn}$ are high where as $\mathrm{Cu}, \mathrm{Pb}$ practically immobile, incase of neutral to alkaline ( $\mathrm{pH}$ 6.7-7.8) soils $\mathrm{Cd}$ and $\mathrm{Zn}$ are moderately mobile Aydinalp and Marinova (2003) and Mousavi (2010). Regarding the EC, there was a slight significant increase among the treatments at the end of $16^{\text {th }}$ year $\left(32^{\text {th }}\right.$ crop) as compared initial soil, but the values are well below the normal rice soil ( 0.4 to 0.62 $\mathrm{dS} / \mathrm{m})$. This might be due to the fluctuation of EC in the submerged rice system through the dissolution of salts from soil, water and the release of ionic species from reduction process. However this will stabilize after some times.

The organic carbon is an important component, because it tends to either soluble form or sub-soluble complexes with the heavy metals, to migrate, or to be retained in the soil (Mousavi, 2010). The percentage of organic carbon (OC) present in the treatments ranged between 0.62 (absolute control) to 0.78 (NPK), a slight significant increase among the treatments was noticed. The increase in the available $\mathrm{N}, \mathrm{P}$ and $\mathrm{K}$ in their respective treatment plots over control was due to the continuous addition of inorganic fertilizers.

Influence of LTFE on total and DTPA extractable heavy metals: The surface $(0-15 \mathrm{~cm})$ and subsurface $(15-30 \mathrm{~cm})$ soil samples were collected and subjected for total and DTPA extractable heavy metals included $\mathrm{Cd}, \mathrm{Pb}, \mathrm{Cu}$ and $\mathrm{Zn}$ analysis. The roots of most of the cereal crops are located in surface zone (Ross, 1994, Mico et al., 2007). In this present study the samples taken from surface soil in all the treatment plots showed relatively higher heavy metal accumulation than subsurface soil. This was in concordance with the findings of Khaled (2004). Among the treatments, highest concentration was generally recorded in NPK application while the least was in the control plots. This was in accordance with the study of Palaniappan et al. (2002), who reported that incorporation of 
Table 2. Physico-chemical properties of soil after harvest of Kharif- 2010 rice crop.

\begin{tabular}{|c|c|c|c|c|c|c|c|}
\hline \multirow{2}{*}{ Properties } & \multicolumn{6}{|c|}{ Fertilizer treatments (Sub plot) } & \multirow[b]{2}{*}{ Mean } \\
\hline & Control & $+\mathbf{P K}$ & $+\mathbf{N}$ & $+\mathrm{NP}$ & $+\mathrm{NK}$ & + NPK & \\
\hline $\mathrm{pH}$ & 7.16 & 7.17 & 7.22 & 7.22 & 7.23 & 7.22 & 7.20 \\
\hline $\mathrm{EC}(\mathrm{dS} / \mathrm{m})$ & 0.53 & 0.54 & 0.54 & 0.54 & 0.54 & 0.58 & 0.55 \\
\hline Org. C (\%) & 0.62 & 0.66 & 0.70 & 0.74 & 0.65 & 0.78 & 0.69 \\
\hline Avail. N (kg/ha) & 175 & 181 & 216 & 246 & 240 & 256 & 219.0 \\
\hline Avail. P (kg/ha) & 40.0 & 61.7 & 43.6 & 61.4 & 46.2 & 70.9 & 53.97 \\
\hline Avail. K (kg/ha) & 127 & 267 & 128 & 269 & 279 & 291 & 226.8 \\
\hline
\end{tabular}

fertilizer viz., single super phosphate containing heavy metals is the source of contamination in cultivated lands (medium black soil).

Phosphotic fertilizers like superphosphate derived from the phosphatic rocks are the chief sources of heavy metals. Mostly, plant absorbs heavy metals from the surface zone $(0-15 \mathrm{~cm})$. The surface zone is mostly affected by pollutants like heavy metals resulting from anthropogenic activities (Machiwa, 2010). The total $\mathrm{Cd}$ content of soil ranged between $1.07 \mathrm{mg} / \mathrm{kg}$ (absolute control) to $3.36 \mathrm{mg} / \mathrm{kg}$ (NPK) with the mean of $2.18 \mathrm{mg} / \mathrm{kg}$ (Fig. 1). The treatments except P fertilizer ( $\mathrm{N}$ alone and $\mathrm{NK}$ treatments) were recorded low total $\mathrm{Cd}$ content, it indicates that the presence of $\mathrm{Cd}$ was due to the application of phosphotic fertilizers. This was in accordance with the findings of Palaniappan et al. (2002).

The total $\mathrm{Pb}$ content of the soil varied from $34.99 \mathrm{mg} /$ $\mathrm{kg}$ (absolute control) to $62.47 \mathrm{mg} / \mathrm{kg}$ (NPK). The total $\mathrm{Pb}$ content was found to be relatively high in $\mathrm{K}$ applied

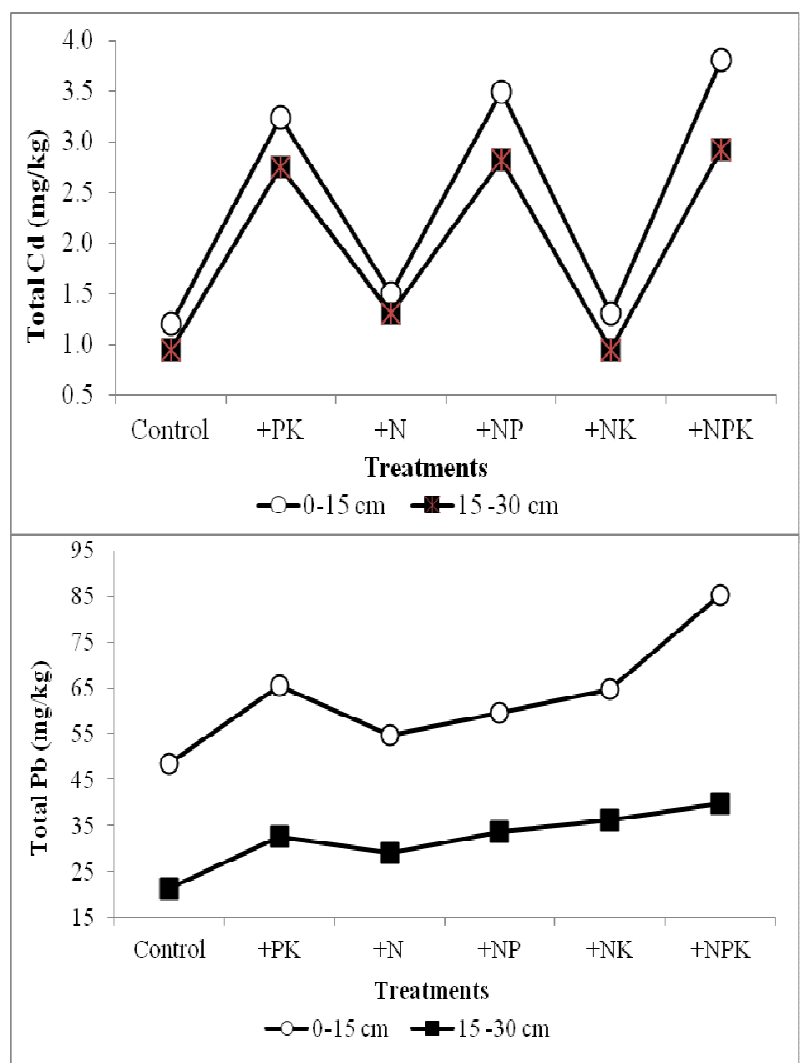

Fig. 1. Total Cd and Pb concentrations in LTFE soils. treatments than others (Fig. 1). Since, the fertilizer single superphosphate, the major $\mathrm{P}$ source in the long term application, it contributes on an average about $106 \mathrm{mg}$ of $\mathrm{Pb}$ per $\mathrm{kg}$ of the fertilizer and hence there is a build up of total $\mathrm{Pb}$ content in soil. Surface soil samples showed relatively higher total $\mathrm{Cu}$ and $\mathrm{Zn}$ accumulation than subsurface soil. The total $\mathrm{Cu}$ content of the soil ranged between from $72.85 \mathrm{mg} / \mathrm{kg}$ (absolute control) to $105.6 \mathrm{mg} / \mathrm{kg}$ (NPK) with the mean $86.16 \mathrm{mg} / \mathrm{kg}$. The total $\mathrm{Cu}$ content was found to be relatively high in $\mathrm{P}$ applied treatment plots than others. It showed that the total $\mathrm{Cu}$ in soil was found to be associated with $\mathrm{P}$ fertilizers. The total $\mathrm{Zn}$ content of the soil varied from $96.85 \mathrm{mg} / \mathrm{kg}$ (absolute control) to $186.5 \mathrm{mg} / \mathrm{kg}$ (NPK) with the mean $143.6 \mathrm{mg} / \mathrm{kg}$ (Fig.2). The total $\mathrm{Zn}$ content was found to be relatively high in $\mathrm{K}$ applied treatments. With respect to depth of soil, the total metal contents were recorded higher in surface soil than subsurface. This might be due to the high organic matter content and anthropogenic activi-

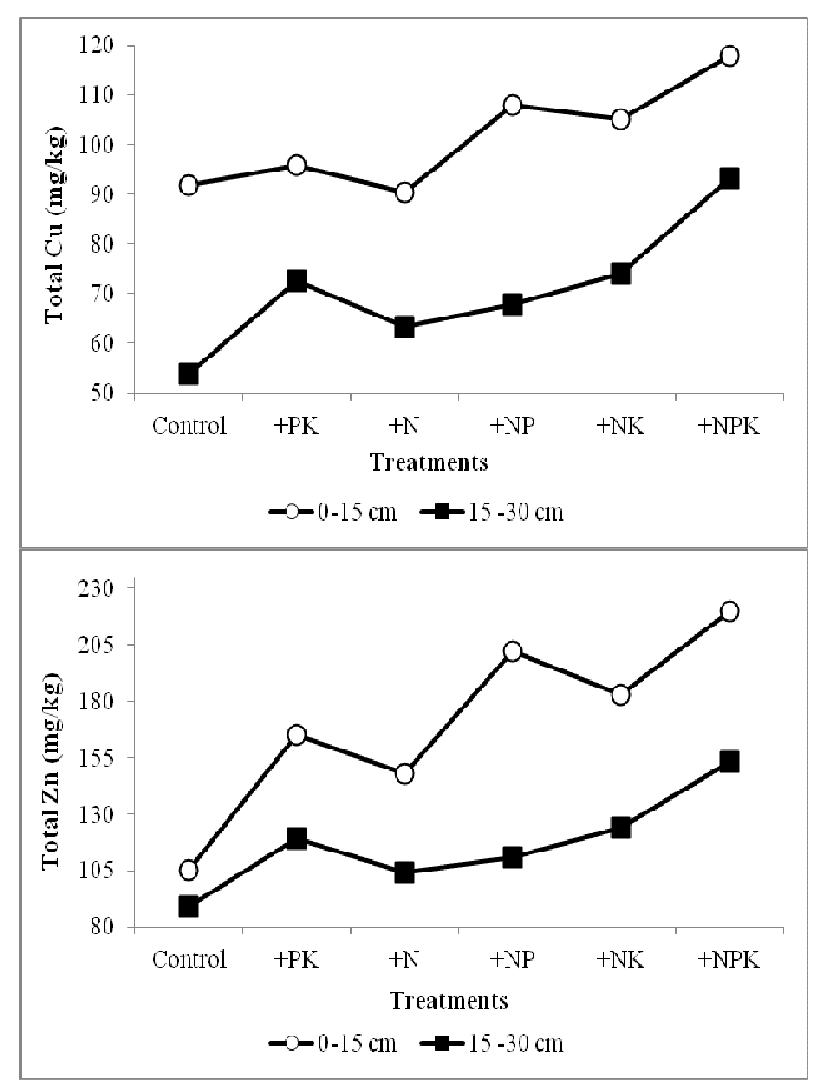

Fig. 2. Total $\mathrm{Cu}$ and $\mathrm{Zn}$ concentrations in LTFE soils. 


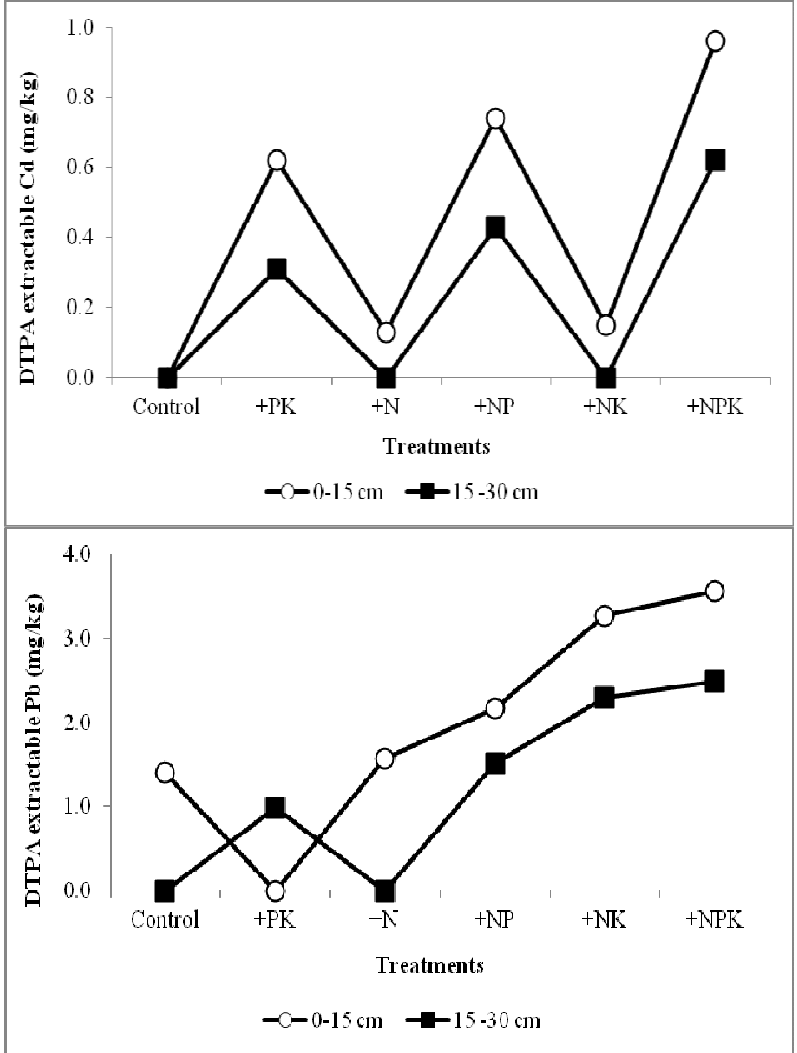

Fig.3. DTPA extractable $C d$ and $P b$ concentrations in LTFE soils.

ties. This result is in confirmation with the findings of Machiwa (2010) who reported that plants absorb heavy metals from soil, the surface $25 \mathrm{~cm}$ depth zone of soil is most affected by heavy metals accumulate in this soil layer due to the relatively high organic matter content. This depth zone is also where roots of most cereal crops are located.

It was observed that DTPA extractable Cd content of the soil ranged from below detectable limit (BDL) (absolute control) to $0.79 \mathrm{mg} / \mathrm{kg}$ (NPK) with the mean $0.33 \mathrm{mg} / \mathrm{kg}$, where the total Cd content was relatively higher, it indicates that the $\mathrm{Cd}$ present in soil is immobile form (Fig. 3). Both total and DTPA extractable Cd content was found to be relatively high in $\mathrm{P}$ applied treatment plots than others. It showed that the $\mathrm{Cd}$ was found to be associated with $\mathrm{P}$ fertilizers. The Palaniappan et al. (2002), who reported that the cadmium accumulation is due to long term addition of phosphatic fertilizer. The single super phosphate addition resulted in higher available and total cadmium for plant uptake than others.

The available $\mathrm{Pb}$ content of the soil differed from 0.71 $\mathrm{mg} / \mathrm{kg}$ (absolute control) to $3.03 \mathrm{mg} / \mathrm{kg}$ (NPK) with the mean $1.81 \mathrm{mg} / \mathrm{kg}$ (Fig.3). The available $\mathrm{Pb}$ content was found to be relatively high in $\mathrm{K}$ applied treatment plots than others. The available $\mathrm{Pb}$ content was found to be BDL in the most of the treatments at subsurface soil. This result indicates that, most of the total and available heavy metal contents were found to be in top layer $(0-15 \mathrm{~cm})$ of the soil.

The surface soil showed relatively higher bioavailable

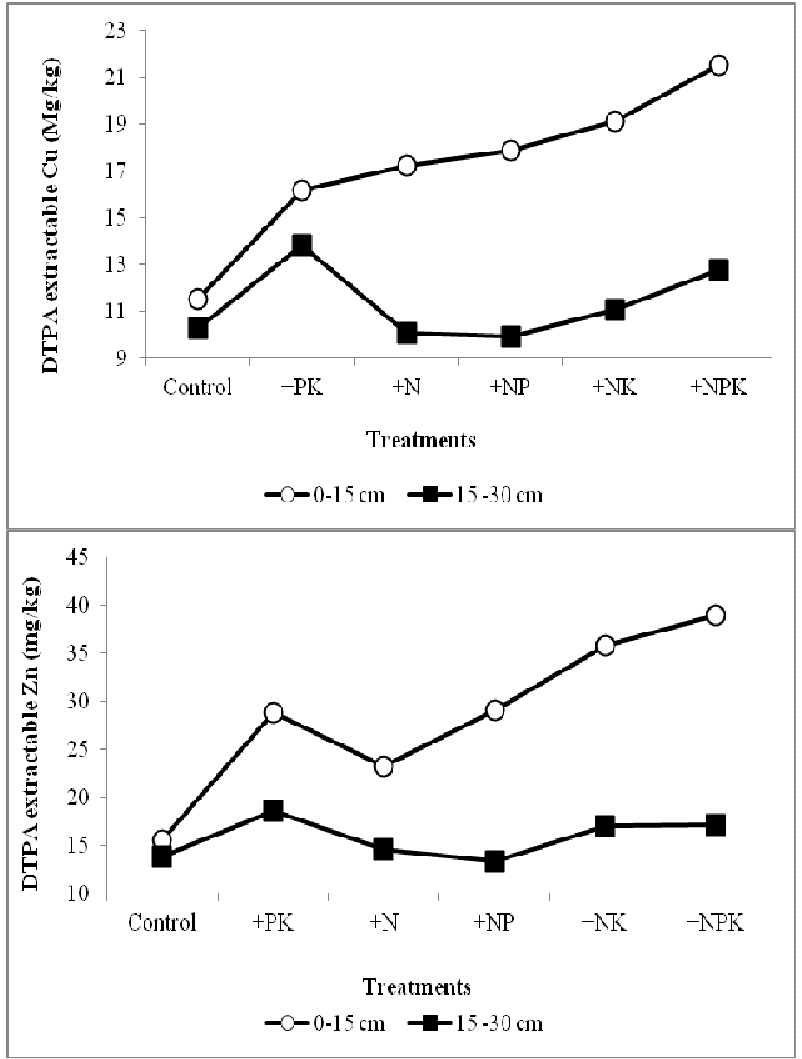

Fig.4. DTPA extractable $C u$ and $Z n$ concentrations in LTFE soils.

$\mathrm{Cu}$ and $\mathrm{Zn}$ accumulation than subsurface soil (Fig. 4). The DTPA extractable $\mathrm{Cu}$ content of the soil ranged between $10.88 \mathrm{mg} / \mathrm{kg}$ (absolute control) to $17.13 \mathrm{mg} / \mathrm{kg}$ (NPK). The available $\mathrm{Cu}$ content was found to be relatively high in $\mathrm{P}$ applied treatments than others. The DTPA extractable $\mathrm{Zn}$ content of the soil varied between $14.69 \mathrm{mg} / \mathrm{kg}$ (absolute control) to $28.12 \mathrm{mg} /$ $\mathrm{kg}(\mathrm{NPK})$ with the mean $22.19 \mathrm{mg} / \mathrm{kg}$. As like that of $\mathrm{Cu}$, available $\mathrm{Zn}$ content was found to be relatively high in $\mathrm{K}$ applied treatments than others. It showed that long term application of phosphotic and $\mathrm{K}$ fertilizers increased the available $\mathrm{Zn}$ content in the soil.

Among the total metal content, $\mathrm{Zn}$ exhibited higher concentration $(143.6 \mathrm{mg} / \mathrm{kg})$, followed by $\mathrm{Cu}(86.16$ $\mathrm{mg} / \mathrm{kg}), \mathrm{Pb}(47.62 \mathrm{mg} / \mathrm{kg})$ and $\mathrm{Cd}(2.18)$. This is in line with the findings of Williams, 1977. He reported that there was an increase in the total lead content of soil over a period of eight years due to the application of zinc sulphate and single super phosphate. All the studied heavy metals exhibited higher concentration in surface soil than subsurface in both total and DTPA extractable metals. This may be due to less vertical mobility of heavy metals in clay soils.

There was no significant difference in the DTPA extractable $\mathrm{Cd}$ in the control when compared to 1994 soils. But the total $\mathrm{Cd}$ was found higher indicating that $\mathrm{Cd}$ was in unavailable form. There was slight increase in the available $\mathrm{Pb}(0.41 \mathrm{mg} / \mathrm{kg}$ in surface soil $)$ but in case of DTPA, extractable $\mathrm{Cu}$ and $\mathrm{Zn}$ heavy increase was noticed.

Heavy metal content in grains: The recommended 
limit of heavy metals in rice grain is $\mathrm{Cd} 0.2 \mu \mathrm{g} / \mathrm{g}, \mathrm{Pb}$ $0.2 \mu \mathrm{g} / \mathrm{g}, \mathrm{Cu} 20 \mu \mathrm{g} / \mathrm{g}$ and $\mathrm{Zn} 50 \mu \mathrm{g} / \mathrm{g}$ (FAO/WHO, 2002). Cadmium is among the most geochemically mobile toxic metals, which is readily taken up by plants and translocated into aerial plants where it accumulates (Machiwa, 2010). Lokhande and Kalkar (1999) reported that studies have demonstrated that high concentration of toxic heavy metals such as $\mathrm{Cd}$, $\mathrm{Pb}$ reduce soil fertility and agricultural output. Indeed $\mathrm{Cd}$ concentration above $20 \mu \mathrm{g} / \mathrm{g}$ in soil reduces rice plant biomass by poisoning the roots and restricting growth (Herawati et al., 2000).

The concentration of mean $\mathrm{Cd}$ in control was below detectable limit and it was high in NPK treated plot $(0.12 \mu \mathrm{g} / \mathrm{g})$. There is no significant difference among varieties on $\mathrm{Cd}$ content but significant difference was noticed under fertilizer treatments, it indicates that this difference was due to long term application of fertilizers (Table 3$)$. The mean $\mathrm{Cd}(0.06 \mu \mathrm{g} / \mathrm{g})$ content was below the maximum allowable limit of $0.2 \mu \mathrm{g} / \mathrm{g}$ (FAO / WHO 2002). Even though the soil contains higher amount of $\mathrm{Cd}(3.8 \mathrm{mg} / \mathrm{kg})$, very less amount is translocated into different parts of paddy. This indicates the presence of more amount of residual form of $\mathrm{Cd}$ in soil.

The concentration of mean $\mathrm{Pb}$ in grain was $0.14 \mu \mathrm{g} / \mathrm{g}$ among all the varietal and fertilizer treatments. It is not significantly differ between varietal treatments, but significantly differ among fertilizer treatments. This study was in concurrence with the findings of Ramachandran et al., 1998. They reported that the application of rock phosphate to cultivated paddy areas in India caused an increase in the $\mathrm{Cd}$ content of rice grain. In paddy grain, the mean concentration of $\mathrm{Cu}$ in control was low $(1.14 \mu \mathrm{g} / \mathrm{g})$ and it was relatively high in all the fertilizer treatments, but peak in NPK treated plots $(10.67 \mu \mathrm{g} / \mathrm{g})$. The significant variation $(\mathrm{P}<0.05)$ was noticed among varieties and treatments. More $\mathrm{Cu}$ was associated with the non-residual fraction like organic form in soil which increases the potential $\mathrm{Cu}$ mobility and bio-availability (Ma and Rao, 1997). The lowest concentration of $\mathrm{Zn}$ in grain was $5.02 \mu \mathrm{g} / \mathrm{g}$ in control and the highest concentration was recorded in the NPK received treatments $(41.68 \mathrm{mg} / \mathrm{kg})$. The mean concentration of $\mathrm{Zn}$ present in grain was $28.79 \mu \mathrm{g} / \mathrm{g}$ over all the varietal and fertilizer treatments (Table 4).

Sixteen years of cultivation and continuous fertilizer addition have not resulted in significant changes in the concentration of DTPA extractable cadmium probably due to crop removal of the metal and higher adsorption of heavy metals by clay humus complex and also possibly due to the conversion of bioavailable form into other forms. Addition of heavy metals through heavy metal containing fertilizers apart from crop residue incorporation in the last sixteen years, however, has resulted in considerable build up so as to manifest in significantly differing concentrations under the variables introduced as revealed by the heavy metal content of soil during the year 2010. On the other hand marked differences in the total heavy metal content could be observed among the treatments introduced during the year 1994 and 2010.

The actual annual additions may vary since the $\mathrm{Cd}$ content of fertilizer may not be constant as reported by Mortvedt (1996) it is very difficult to estimate the accumulation of $\mathrm{Cd}$ and other heavy metals applied to agricultural soils with $P$ fertilizers because the mechanism of addition and removal cannot be assessed easily. Naturally there is an increase in the cadmium content of soil.

$\mathrm{Cd}$ accumulation due to phosphatic fertilizer addition to soil has been very well documented. Loganathan et al. (1997) while studying the effect of continuous addition for ten years of four phosphatic fertilizers of differing cadmium content and among this single super phosphate addition resulted in higher plant available ant total cadmium than other phosphatic fertilizers. The urea added in the $\mathrm{N}$ alone treatment had negligible cadmium concentration. In present study, there was an increase in the $\mathrm{Cd}, \mathrm{Cu}$ and $\mathrm{Zn}$ of soil over a period of eight years in all the treatments including control. The increase in the control as well as $\mathrm{N}$ alone plots could

Table.3. Influence of long term fertilization on $\mathrm{Cd}$ and $\mathrm{Pb}$ content of grain.

\begin{tabular}{|c|c|c|c|c|c|c|c|}
\hline \multirow{3}{*}{\multicolumn{2}{|c|}{ Treatments }} & \multicolumn{6}{|c|}{ Heavy metal concentration $(\mu \mathrm{g} / \mathrm{g})$} \\
\hline & & \multicolumn{3}{|c|}{ Cd } & \multicolumn{3}{|c|}{$\mathbf{P b}$} \\
\hline & & ADT 43 & ADT 45 & Mean & ADT 43 & ADT 45 & Mean \\
\hline$\overline{T_{1}}$ & Control & BDL & BDL & 0 & 0.08 & 0.10 & 0.09 \\
\hline $\mathrm{T}_{2}$ & $+\mathrm{PK}$ & 0.11 & 0.10 & 0.11 & 0.13 & 0.14 & 0.14 \\
\hline $\mathrm{T}_{3}$ & $+\mathrm{N}$ & BDL & BDL & 0.00 & 0.12 & 0.12 & 0.12 \\
\hline $\mathrm{T}_{4}$ & $+\mathrm{NP}$ & 0.11 & 0.11 & 0.11 & 0.18 & 0.17 & 0.18 \\
\hline $\mathrm{T}_{5}$ & $+\mathrm{NK}$ & 0.05 & 0.03 & 0.04 & 0.12 & 0.11 & 0.12 \\
\hline $\mathrm{T}_{6}$ & $+\mathrm{NPK}$ & 0.12 & 0.11 & 0.12 & 0.17 & 0.18 & 0.18 \\
\hline \multirow{2}{*}{\multicolumn{2}{|c|}{ Mean }} & 0.07 & 0.06 & 0.06 & 0.13 & 0.14 & 0.14 \\
\hline & & SEd & CD $(0.05 \%)$ & & & SEd & CD $(0.05 \%)$ \\
\hline \multicolumn{2}{|c|}{ Variety (V) } & 0.002 & NS & & Variety (V) & 0.002 & NS \\
\hline \multicolumn{2}{|c|}{ Treatment(T) } & 0.004 & 0.008 & & Treatment(T) & 0.005 & 0.01 \\
\hline \multicolumn{2}{|c|}{$\mathbf{V} \mathbf{X} T$} & 0.005 & NS & & V X T & 0.007 & 0.02 \\
\hline \multicolumn{2}{|c|}{$\mathbf{T X V}$} & 0.006 & 0.012 & & T X V & 0.007 & 0.02 \\
\hline
\end{tabular}

BDL: Below Detectable Limit, NS: Non-significant. 
Table. 4. Influence of long term fertilization on $\mathrm{Cu}$ and $\mathrm{Zn}$ content of grain.

\begin{tabular}{|c|c|c|c|c|c|c|c|}
\hline & & \multicolumn{6}{|c|}{ Heavy metal concentration $(\mu \mathrm{g} / \mathrm{g})$} \\
\hline \multicolumn{2}{|c|}{ Treatments } & \multicolumn{3}{|c|}{$\mathbf{C u}$} & \multicolumn{3}{|c|}{ Zn } \\
\hline & & ADT 43 & ADT 45 & Mean & ADT 43 & ADT 45 & Mean \\
\hline $\mathrm{T}_{1}$ & Control & 1.17 & 1.11 & 1.14 & 5.36 & 4.68 & 5.02 \\
\hline $\mathrm{T}_{2}$ & $+\mathrm{PK}$ & 5.68 & 5.26 & 5.47 & 29.48 & 23.8 & 26.64 \\
\hline $\mathrm{T}_{3}$ & $+\mathrm{N}$ & 6.74 & 4.78 & 5.76 & 24.45 & 27.8 & 26.13 \\
\hline $\mathrm{T}_{4}$ & $+\mathrm{NP}$ & 9.91 & 8.36 & 9.14 & 33.26 & 37.68 & 35.47 \\
\hline $\mathrm{T}_{5}$ & $+\mathrm{NK}$ & 9.68 & 10.07 & 9.88 & 36.87 & 38.69 & 37.78 \\
\hline $\mathrm{T}_{6}$ & $+\mathrm{NPK}$ & 10.98 & 10.35 & 10.67 & 39.79 & 43.57 & 41.68 \\
\hline \multirow{2}{*}{\multicolumn{2}{|c|}{ Mean }} & 7.36 & 6.66 & 7.01 & 28.20 & 29.37 & 28.79 \\
\hline & & SEd & $\mathrm{CD}(0.05 \%)$ & & & SEd & $\mathrm{CD}(0.05 \%)$ \\
\hline \multicolumn{2}{|c|}{ Variety (V) } & 0.08 & 0.35 & & Variety $(\mathbf{V})$ & 0.34 & NS \\
\hline \multicolumn{2}{|c|}{ Treatment(T) } & 0.35 & 0.73 & & Treatment(T) & 1.37 & 2.86 \\
\hline \multicolumn{2}{|c|}{$\mathbf{V} \mathbf{X} \mathbf{T}$} & 0.46 & 0.99 & & $\mathbf{V} \times \mathbf{T}$ & 1.80 & 3.90 \\
\hline \multicolumn{2}{|c|}{$\mathbf{T X} \mathbf{V}$} & 0.49 & 1.03 & & $\mathbf{T ~ X ~ V ~}$ & 1.94 & 4.04 \\
\hline
\end{tabular}

BDL: Below Detectable Limit, NS: Non-significant.

Table. 5. Influence of long term fertilization on $\mathrm{Cd}$ and $\mathrm{Pb}$ content of straw.

\begin{tabular}{|c|c|c|c|c|c|c|c|}
\hline & & \multicolumn{6}{|c|}{ Heavy metal concentration $(\mu \mathrm{g} / \mathrm{g})$} \\
\hline \multicolumn{2}{|c|}{ Treatments } & \multicolumn{3}{|c|}{ Cd } & \multicolumn{3}{|c|}{$\mathbf{P b}$} \\
\hline & & ADT 43 & ADT 45 & Mean & ADT 43 & ADT 45 & Mean \\
\hline $\mathrm{T}_{1}$ & Control & BDL & BDL & 0 & BDL & BDL & 0 \\
\hline $\mathrm{T}_{2}$ & $+\mathrm{PK}$ & 0.10 & 0.11 & 0.11 & 0.12 & 0.14 & 0.13 \\
\hline $\mathrm{T}_{3}$ & $+\mathrm{N}$ & BDL & BDL & 0.00 & 0.04 & 0.03 & 0.04 \\
\hline $\mathrm{T}_{4}$ & $+\mathrm{NP}$ & 0.11 & 0.12 & 0.12 & 0.13 & 0.11 & 0.12 \\
\hline $\mathrm{T}_{5}$ & $+\mathrm{NK}$ & 0.03 & 0.02 & 0.03 & 0.06 & 0.08 & 0.07 \\
\hline $\mathrm{T}_{6}$ & $+\mathrm{NPK}$ & 0.11 & 0.12 & 0.12 & 0.13 & 0.12 & 0.13 \\
\hline \multirow{2}{*}{\multicolumn{2}{|c|}{ Mean }} & 0.06 & 0.06 & 0.06 & 0.08 & 0.08 & 0.08 \\
\hline & & SEd & $\mathrm{CD}(0.05 \%)$ & & & SEd & $\operatorname{CD}(0.05 \%)$ \\
\hline \multicolumn{2}{|c|}{ Variety $(\mathbf{V})$} & 0.002 & NS & & Variety $(\mathbf{V})$ & 0.002 & NS \\
\hline \multicolumn{2}{|c|}{ Treatment(T) } & 0.004 & 0.008 & & Treatment(T) & 0.004 & 0.009 \\
\hline \multicolumn{2}{|c|}{$\mathbf{V} \mathbf{X} T$} & 0.005 & NS & & $\mathbf{V} \mathbf{X}$ & 0.006 & 0.01 \\
\hline \multicolumn{2}{|c|}{$\mathbf{T} \times \mathbf{V}$} & 0.006 & 0.011 & & $\mathbf{T X V}$ & 0.006 & 0.01 \\
\hline
\end{tabular}

BDL: Below Detectable Limit, NS: Non-significant.

be due to the input from other sources like irrigation water and atmospheric deposits..

Heavy metal content of straw: In paddy straw, the concentration of mean $\mathrm{Cd}$ and $\mathrm{Pb}$ in control was below detectable and the concentration of $\mathrm{Cd}$ and $\mathrm{Pb}$ in NPK treatment was higher $(0.06 \%$ and $0.08 \%$ of $\mathrm{Cd}$ and $\mathrm{Pb}$, respectively). Heavy metal content between varietal treatments was non significant but some remarkable significance $(\mathrm{P}<0.05)$ was noticed under fertilizer treatments (Table 5). The mean $\mathrm{Pb}$ concentration present in straw was $0.08 \mu \mathrm{g} / \mathrm{g}$ among all the fertilizer and varietal treatments. The critical difference $(0.05 \%)$ was non-significant on varietal treatments and some remarkable significance was noticed under fertilizer treatments. This showed the application of fertilizers had influence on concentration of $\mathrm{Cd}$ and $\mathrm{Pb}$ content of paddy straw.

$\mathrm{Cd}$ and $\mathrm{Pb}$ were evenly distributed at low concentrations in grain and straw at various treatments, $\mathrm{Cu}$ and $\mathrm{Zn}$ was found relatively higher in grains and paddy straw among various fertilizer treatments. But there was no much difference among the varietal treatments for the accumulation of heavy metals. It was in accordance with the statement of Pendias and Pendias (2001) that the pesticides and fertilizers are known to be the main sources of heavy metal pollution. Jarvis et al. (1976) reported that Cd was easily taken up by plants and transported to different organs although it had no beneficial effects to plants and animals. Phosphotic fertilizers like superphosphate derived from the phosphatic rocks are the chief sources of heavy metals like cadmium and lead. All the treatment plots applied with $\mathrm{P}$ and $\mathrm{K}$ fertilizers showed high heavy metal accumulation in grains and straw, but the levels are below the maximum permissible limit.

Irrespective of the treatments, variety ADT 43 in both grain and straw recorded higher $\mathrm{Cd}$ and $\mathrm{Cu}$ content, incase of ADT 45 higher amount of $\mathrm{Pb}$ and $\mathrm{Zn}$ was recorded (Table 6). These heavy metal contents in grain and straw were below the maximum permissible 
Table.6. Influence of long term fertilization on $\mathrm{Cu}$ and $\mathrm{Zn}$ content of straw.

\begin{tabular}{|c|c|c|c|c|c|c|c|}
\hline \multirow{2}{*}{\multicolumn{2}{|c|}{ Treatments }} & \multicolumn{6}{|c|}{ Heavy metal concentration $(\mu \mathrm{g} / \mathrm{g})$} \\
\hline & & \multicolumn{3}{|c|}{$\mathrm{Cu}$} & \multicolumn{3}{|c|}{$\mathbf{Z n}$} \\
\hline & & ADT 43 & ADT 45 & Mean & ADT 43 & ADT 45 & Mean \\
\hline $\mathrm{T}_{1}$ & Control & 1.12 & 1.64 & 1.38 & 3.71 & 3.21 & 3.46 \\
\hline $\mathrm{T}_{2}$ & $+\mathrm{PK}$ & 3.15 & 3.26 & 3.21 & 26.84 & 24.48 & 25.66 \\
\hline $\mathrm{T}_{3}$ & $+\mathrm{N}$ & 4.79 & 2.15 & 3.47 & 25.25 & 23.18 & 24.22 \\
\hline $\mathrm{T}_{4}$ & $+\mathrm{NP}$ & 7.08 & 6.38 & 6.73 & 23.22 & 20.35 & 21.79 \\
\hline $\mathrm{T}_{5}$ & $+\mathrm{NK}$ & 6.38 & 6.29 & 6.34 & 32.99 & 33.82 & 33.41 \\
\hline $\mathrm{T}_{6}$ & $+\mathrm{NPK}$ & 7.93 & 9.68 & 8.81 & 35.38 & 35.46 & 35.42 \\
\hline \multicolumn{2}{|c|}{ Mean } & $\begin{array}{l}5.08 \\
\text { SEd }\end{array}$ & $\begin{array}{c}4.90 \\
\text { CD }(0.05 \%)\end{array}$ & 4.99 & 24.57 & $\begin{array}{c}23.42 \\
\text { SEd }\end{array}$ & $\begin{array}{c}23.99 \\
\mathrm{CD}(0.05 \%)\end{array}$ \\
\hline \multicolumn{2}{|c|}{ Variety (V) } & 0.08 & NS & & Variety (V) & 0.19 & 0.80 \\
\hline \multicolumn{2}{|c|}{ Treatment(T) } & 0.25 & 0.52 & & Treatment(T) & 1.14 & 2.37 \\
\hline \multicolumn{2}{|c|}{$\mathbf{V} \mathbf{X} \mathbf{T}$} & 0.33 & 0.73 & & $\mathbf{V} \mathbf{X} \mathbf{T}$ & 1.48 & NS \\
\hline \multicolumn{2}{|c|}{$\mathbf{T X} \mathbf{V}$} & 0.35 & 0.74 & & $\mathbf{T} \mathbf{X} \mathbf{V}$ & 1.61 & 3.35 \\
\hline
\end{tabular}

BDL: Below Detectable Limit; NS: Non-significant.

limit prescribed by FAO (Food and Agricultural organization, 2002).

\section{Conclusion}

Continuous incorporation of phosphatic fertilizers resulted in the buildup of $\mathrm{Cd}$ and $\mathrm{Pb}$ concentration in surface soils. Accumulations in higher concentrations of these heavy metals are associated with higher level of single super phosphate addition as well as with the addition of zinc sulphate. Though the concentration of these two heavy metals in soil has not reached toxic levels even after sixteen years, the rate of increase necessitates close monitoring the production system involving single superphosphate and zinc application in order to sustain

\section{REFERENCES}

Aydinalp, C. and Marinova, S. (2003). Distribution and forms of heavy metals in some agricultural soils. Polish. J. of Env. Studies, 12(5):629-633.

FAO/WHO (2002). Codex Alimentarius - General standards for contaminants and toxins in food. Schedule1. Maximum and guideline levels for contaminants and toxins for food. Joint FAO/WHO food standards programme, codex committee, Rotterdam, Reference CX/FAC 02/16.

Herawati, N., Suzuki, S., Hayashi, K., Rivai, I.F. and Koyana, H. (2000). Cadmium, Copper and Zinc levels in rice and soils of Japan, Indonesia and China by soil type. Bull. Env. Contam. Toxicol., 64:33-39.

Jarvis, S. C., Jones, L.P. H. and Hopper, M. J. (1976). Cadmium uptake from solutions by plants and its transport from roots to shoots. Plant soil, 44:179-191.

Khaled, Eid M. (2004). Distribution of different fractions of heavy metals in desert sandy soil amended with composted sewage sludge. Intl. conf. on Water Resources \& Arid Environment, P:1-15.

Lindsay, W.L. and Norvell, W.A. (1978). Development of a DTPA soil test for zinc, iron, manganese and copper. Soil Sci. Soc. Am.J., 42:421-428.

Loganathan, P., Helley, M. J., Gregg, P.E.H.and Currie,L.D. (1997). Effect of Phosphatic fertilizer type on the accumulation and plant availability of cadmium in grassland soils. Nut. Cyc. Agroecosys., 47:169-178.

Lokhande, R.S. and Kelkar, N. (1999). Studies on heavy metals in water of Vasai creek, Maharashtra. Indian J. Environ. Protect.,19:664-668.

Ma, L.Q. and Rao, G. N. (1997). Chemical fractionation of cadmium, copper, nickel and zinc in contaminated soils. J. Environ. Qual., 26:259-264.

Machiwa, J. F. (2010). Heavy metal levels in paddy soils and rice (Oryza sativa L.) from wetlands of Lake Victoria Basin, Tanzania, Tanz. J. Sci., 36:59-71.

Mico, C., Peris, M., Racatala, L. and Sanchez, J. (2007). Baseline values for heavy metal in agricultural soils in European Mediterranean region. Sci. Total Environ., 378:13-17.

Mortvedt, J. J. (1996). Heavy metal contaminants in inorganic and organic fertilizers. Fertilizer Research, 43:55-61.

Mousavi, S.M. (2010). Lead and Cadmium availability and uptake by rice plant in response to different bio-solids and inorganic fertilizers. Am. J. Agri. Biol. Sci., (1):2531.

Palaniappan, M., Shanmugam, K. and Ponnusamy, S. (2002). Soil degradation due to heavy metal accumulation under long term fertilization. Symposium no.46, paper no:33, $17^{\text {th }}$ WCSS, 14-21 Aug 2002, Thailand, pp. 333-1-7.

Pendias, A. and Pendias, H. (2001). Trace elements in Soils and Plants. $3^{\text {rd }}$ edn. Boca Raton: CRC Press.

Ponnamperuma (1972). The chemistry of submerged soils. Adv. Agron., 24: 32-96.

Ramachandran, V., Bhujal, B.M. and D'Souza, T. J. (1998). Influence of rock phosphates with and without vegetable compost on the yield, phosphorous and cadmium contents of rice (Oriza sativa) grown on an ultisol. Fresenius Environ. Bull., 7:551-556.

Ross, S. M. (1994). Toxic metals in soil-plant systems. John Wiley and Sons, Inc. Chichester. 469.

USEPA (1979). Method 281.4.Chromium, hexavalent. In: methods for chemical analysis of water and wastes.United States Environmental Protection Agency, EPA-600/4/79-020 (USEPA, Environmental monitoring and support laboratory, Cincinnatte, $\mathrm{OH}$ ).

Williams,C.H.(1977). Trace metals and super phosphate toxicity problems. J. Aust. Inst. Agri. Sci., 43:99-109. 